\title{
35 years of socially responsible investing (SRI) research - General trends over time
}

\author{
S. Viviers* \\ Department of Business Management, University of Stellenbosch, \\ Private Bag X1, Matieland 7602, Republic of South Africa \\ sviviers@sun.ac.za \\ N.S. Eccles \\ Noah Chair in Responsible Investment, Centre for Corporate Citizenship, \\ Unisa Main Campus, Preller Street, Tshwane 0003, Republic of South Africa \\ ecclens@unisa.ac.za
}

Received June 2011

\begin{abstract}
This article describes 35 years of academic research into investment practices that in some way integrate a consideration of environmental, social and corporate governance issues. A review of 190 academic papers was undertaken to identify trends in five domains, namely 'Primary Name', 'Research Themes', 'Ethical Foundations', 'Research Approach' and 'SRI Strategies'. The evidence reveals that more than half the researchers refer to such investment practices as Socially Responsible Investing (SRI) and for this reason the name is used in this review as a generic term for the genre. A myriad of other names were also identified. In terms of research themes, one particularly dominant theme was that of financial performance, which was often discussed in relation to fiduciary responsibility and legal aspects. Although the primary ethical foundation was not always directly observable, the majority of papers implied utilitarianism or 'the greatest good for the greatest number'. Increased mention of ethical egoism (self-interest) is observed in later periods. An equal split between qualitative and quantitative research methodologies was noted, with a qualitative approach being more favoured in recent years. Three SRI strategies have dominated academic discussions over the past 35 years, namely negative screening, positive screening and shareholder activism. Gaps in the literature have been identified and suggestions for future research made.
\end{abstract}

*To whom all correspondence should be addressed.

\section{Introduction}

Investment practices that in some way integrate a consideration of environmental, social and corporate governance (ESG) issues, have a long history, dating back at least as far as the 1700s anti-slavery campaigns of the Quakers (Schueth, 2003: 89). As early as 1928, investment funds catering specifically for the investment needs of religious groups were developed in the USA (Schwartz, 2003: 195). These funds involved screening out certain investments that were not aligned to the moral values of their clientele. By the late 1970s and early 1980s, this movement had transcended the realms of specific religious clientele to a more secular approach. The anti-Vietnam war and anti-apartheid responsible investment movements were prime examples of this (Feigenbaum \& Lowenberg, 1988; Lansing \& Kuruvilla, 1988; Meznar, Nigh \& Kwok, 1998). The basic moral 'rightness' of these two protest SRI movements had a much broader appeal than the earlier religious investment movements.

Since then, variants of this investment genre embracing strategies such as positive screening, best-in-sector screening, shareholder activism, cause-based (targeted) investing and enhanced analytics have become increasingly popular. According to a 2008 European SRI industry study (Eurosif, 2008: 51), significant growth in socially responsible investing (SRI) has been noted in developed markets such as the USA, Canada, Europe and Australia. A 2007 report on socially responsible investing trends in the USA (Social Investment Forum, 2007: ii) indicates that SRI in the USA is growing at a faster pace than the broader universe of all investment assets under professional management. SRI assets in the USA rose by $324 \%$ from $\$ 639$ billion in 1995 to $\$ 2,71$ trillion in 2007. During the same period, the broader universe of assets under professional management increased by only $260 \%$ from $\$ 7$ trillion to $\$ 25,1$ trillion.

With this apparent surge in interest in SRI within the broader investment industry as a backdrop, this article sets out to describe 35 years of academic research into investment practices that in some way integrate a consideration of ESG issues. To do this, we present a narrative overview from January 1975 to March 2009, examining trends in a number of major topics. This historical overview of SRI research contributes to the body of knowledge on SRI by identifying gaps in the existing 
literature and by hinting at paradigm shifts that have occurred over the past 35 years. Several suggestions for future research in the field are made.

\section{Research design and methodology}

In order to trace the conceptual development of this field through 35 years of diverse academic literature, we encoded a sample of 190 academic papers around five key domains, described in Table 1. The coding structure was designed $a$ priori and all coding was done by the authors. In most of the domains, the codes were not mutually exclusive and, where appropriate, papers were assigned multiple codes. In these cases, the sum of percentages presented in the figures and tables may well exceed $100 \%$.
Since the primary purpose of this study was to develop a narrative description of trends over time, we partitioned the encoded data set into six time windows, as presented in Table 2. The first period contains 10 years rather than 5 because of the very small number $(n=3)$ of papers sampled in this period. As the sample was finalised in March 2009, the 2005-2009 period technically comprises only four-anda-quarter years. For the most part, we present the percentage of papers in which particular codes occurred within each particular time period. Percentages are used because of the ease of visualisation in what is a largely graphical data analysis. It is, however, important to bear in mind when examining the results that in the earlier time periods there were far fewer papers than in the later periods.

Table 1: Domains used to characterise papers in the sample

\begin{tabular}{|c|c|}
\hline Domain & Codes \\
\hline \multirow[t]{8}{*}{ Primary Name } & Ethical Investment \\
\hline & Green Investment \\
\hline & Moral Investment \\
\hline & Responsible Investment \\
\hline & South Africa-Free Investment \\
\hline & Social Investment \\
\hline & Socially Responsible Investment \\
\hline & Other \\
\hline \multirow[t]{9}{*}{ Research Themes } & Ethical Foundations \\
\hline & ESG Performance \\
\hline & Fiduciary Responsibility \\
\hline & Financial Performance <characterised as,+ 0 or $->$ \\
\hline & Impact \\
\hline & Investor Motives \\
\hline & Legal Aspects \\
\hline & Universal Ownership \\
\hline & Other \\
\hline \multirow[t]{6}{*}{ Research Approach } & Analysis of Statistical Data \\
\hline & Case Studies \\
\hline & Experimental \\
\hline & In-Depth Interviews \\
\hline & Surveys \\
\hline & Theoretical Studies or Literature Reviews \\
\hline \multirow[t]{6}{*}{ Ethical Foundations } & Deontological \\
\hline & Ethical Egoism \\
\hline & Ethics of Care \\
\hline & Utilitarianism \\
\hline & Ambiguous \\
\hline & Multiple \\
\hline \multirow[t]{7}{*}{ SRI Strategies } & Best-in-Sector \\
\hline & Cause-based (targeted) Investing \\
\hline & Enhanced Analytics \\
\hline & Negative Screening \\
\hline & Positive Screening \\
\hline & Shareholder Activism \\
\hline & Other \\
\hline
\end{tabular}


Table 2: Number of SRI articles published over time

\begin{tabular}{l|r|c}
\hline \multicolumn{1}{c|}{ Period } & N & \% of publications \\
\hline $1975-1984$ & 3 & 1,6 \\
\hline $1985-1989$ & 4 & 2,1 \\
\hline $1990-1994$ & 13 & 6,8 \\
\hline $1995-1999$ & 33 & 17,4 \\
\hline $2000-2004$ & 44 & 23,2 \\
\hline $2005-2009$ & 93 & 48,9 \\
\hline Total & $\mathbf{1 9 0}$ & $\mathbf{1 0 0 , 0}$ \\
\hline
\end{tabular}

This sample of 190 papers was obviously not exhaustive. It was restricted to papers that were available to the authors through their respective institutional libraries, or in their personal collections. The focus was on academic literature only. No conference proceedings or books on the topic were included. Arguably the most significant limitation of the sampling approach, however, was the restriction to Englishlanguage publications. As a possible future research avenue, it may be of interest to examine whether the trends discussed are mirrored or altered by the inclusion of literature in other languages (e.g. French-language literature including papers such as Deborde, Minczeles \& Sicard, 2006; Deheuvels, 2006; Dejean, 2008; Delahousse, 2006; Gond, 2006; Louche \& Lydenberg, 2006; Renaudin, 2006).

As indicated in Table 3, most of the research on the topic has taken place in North America and the United Kingdom. In recent years, more publications have seen the light in Scandinavian countries and across regions. Very little research has been done in Africa (outside of South Africa) and other emerging economies.
Table 3: Regions covered in the sample of academic literature considered

\begin{tabular}{l|c}
\hline Region & N \\
\hline Africa & 15 \\
\hline Australasia & 15 \\
\hline Europe (excluding the United Kingdom) & 28 \\
\hline North America & 76 \\
\hline Scandinavia & 8 \\
\hline United Kingdom & 40 \\
\hline Not Country-Specific & 40 \\
\hline $\begin{array}{l}\text { Note: the sum of N exceeds 190 because many papers describe } \\
\text { research covering multiple regions. }\end{array}$
\end{tabular}

Despite these limitations, 190 papers are still a large sample of literature. It contains papers from no less than 77 periodicals from a range of disciplines (Figure 1). Over time, there has been a reasonably consistent representation of journals in the Finance/Economics/Investment category. In terms of other disciplines, Management/General Business journals were particularly well represented earlier in the time series, while journals specialising in Ethics/Business Ethics/Philosophy and Corporate Social Responsibility/Sustainability/Development have come to be more represented in recent years. This is perhaps due to the more recent emergence of journals specialising in these disciplines. For example, the Journal of Business Ethics (the most frequently appearing periodical in this sample) was first published in 1982 .

What follows in the remainder of this paper is a narrated presentation of empirical trends in the five key domains of 'Primary Name', 'Research Themes', 'Ethical Foundations', 'Research Approach' and 'SRI Strategies'.

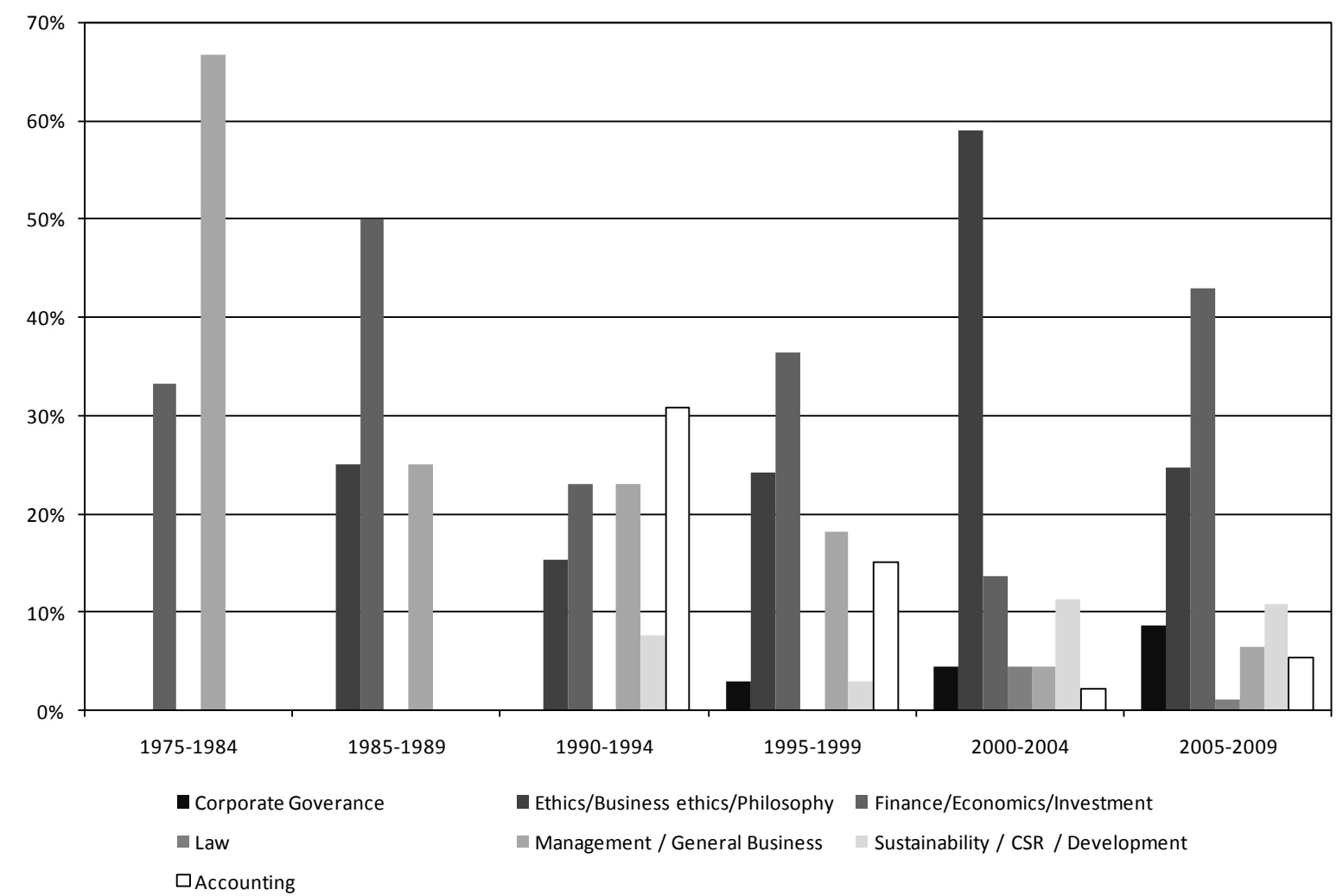

Figure 1: Frequency of papers per discipline over time 


\section{Results and narrative}

\section{Primary name}

Over the years, the academic literature has referred to a variety of investment practices that integrate a consideration of ESG issues, by a bewildering array of names. Some of the more common names to have emerged include: social investment (e.g. Dunfee, 2003; Cox, Brammer \& Millington, 2007); ethical investment (e.g. Irvine, 1987; Mackenzie, 1998; Schwartz, Tamari \& Schwab, 2007); green investment (e.g. White, 1995; Heinkel, Kraus \& Zechner, 2001; Randjelovic, O'Rourke \& Orsato, 2003); sustainability/sustainable investment (e.g. Weber, 2005; Koellner, Sangwon, Weber, Moser \& Scholz, 2007) and responsible investment (e.g. Dembinski, Bonvin, Dommen \& Monnet, 2003; Thamotheram \& Wildsmith, 2007; Viviers, Bosch, Smit \& Buijs, 2009).

In addition to these, a range of other more obscure names also appear, including community investing; environmentally responsible investing; faith-based investing; mission-based or mission-related investing; moral investing; social-choice investing, and so on. However, by far the most commonly used primary name for investment practices that capture a consideration of ESG issues is 'socially responsible investment' (SRI) (Figure 2). It is for this reason, rather than any specifically accepted definition, that SRI was selected as a generic name describing this genre of investment for the purpose of this review.

Examining the occurrence in the literature of names over time reveals that commonly occurring names today were not necessarily the first names that were used to describe such investment activities (Figure 3). Early on in the development of this field as an area of academic consideration (1970s and 1980s), social investment and some of the more uncommon 'other' names appear to have prevailed in the literature (Figure 3). The period from the very late 1980s through to the late 1990s appears to have been a period of flux. In the late 1980s, ethical investment began to emerge, and by the 1990-1994 window, was the dominant primary name used in this sample of the literature. This dominance was, however, short-lived, as SRI made its debut in the sample during this period (1990-1994) and became increasingly dominant in all subsequent periods.

While SRI remains the dominant name today, it does appear that a number of newer names have begun to appear. From 2000 onwards, responsible investment has begun to make an appearance in the academic literature. Even more recently, 'sustainable investment' has been become more popular. Although it is technically still an obscure name in this sample and presumably in the broader literature, there is evidence that this is likely to change soon, particularly in light of a new academic journal entitled 'Journal of Sustainable Finance \& Investment’ launched in 2010.

\section{Research themes}

As indicated in Table 4, the most frequently researched theme in this sample was that of the financial performance of SRI funds vis-à-vis traditional (non-SRI funds) and broad market indices. This is followed by studies on the measurement of ESG performance of investee companies and the ethical foundations of SRI.

When considering trends over time (Figure 4), it is clear that researchers' concerns about financial performance, fiduciary responsibility and legal issues have become proportionally less frequent in recent years. Themes relating to universal ownership and the impact of SRI strategies on corporate policies and practices have become proportionally more represented in the sample.

\section{Financial performance as a theme in SRI research}

Studies on financial performance can generally be categorised into three groups, namely:

- $\quad$ studies comparing the performance of artificially constructed SRI funds vis-à-vis market and conventional indices (e.g. Rudd, 1979; Grossman \& Sharpe, 1986; Diltz, 1995a, 1995b; Guerard, 1997a, 1997b, 1997c; Hutton, D’Antonio \& Johnsen, 1998);

- $\quad$ studies investigating the performance of SRI indices against market and conventional indices (Kurtz \& DiBartolomeo, 1996; Sauer, 1997; Statman, 2000); and

- $\quad$ studies evaluating the performance of actual SRI funds vis-à-vis market indices, other benchmark indices and conventional (non-SRI) funds (e.g. Hamilton, Jo \& Statman, 1993; White, 1995; Gregory, Matatko \& Luther, 1997; Reyes \& Grieb, 1998; Goldreyer \& Diltz, 1999; Cummings, 2000; Statman, 2000; Bauer, Koedijk \& Otten, 2005; Kreander, Gray, Power \& Sinclair, 2005; Mill, 2006; Fernandez-Izquierdo \& MatallinSaez, 2008). 


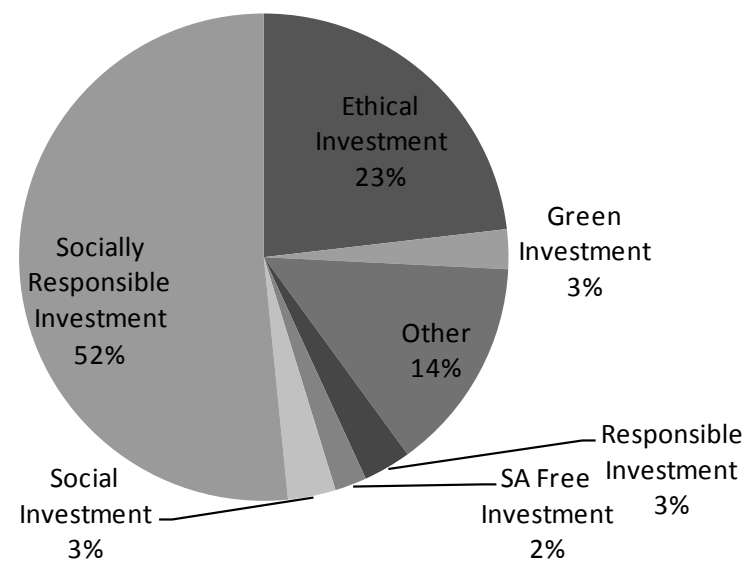

Figure 2: The appearance and frequency of names for investment practices that in some way integrate a consideration of ESG issues

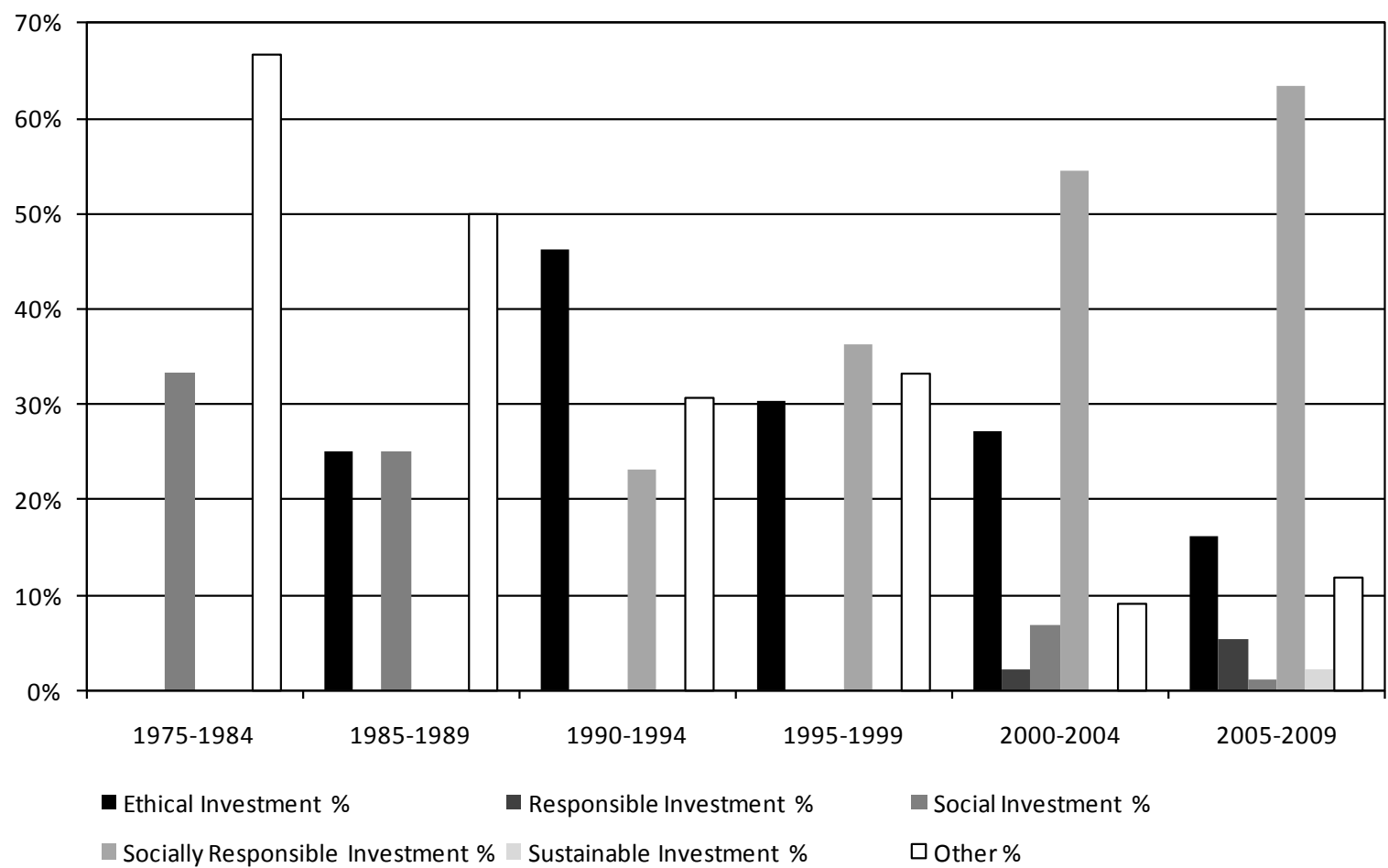

Figure 3: Frequency of the occurrence of names for investment practices that integrate a consideration of ESG issues

Table 4: Research themes

\begin{tabular}{l|c|c}
\hline \multicolumn{1}{c|}{ Theme } & N & \% of publications \\
\hline Financial Performance & 59 & 31,1 \\
\hline ESG Performance & 28 & 14,7 \\
\hline Ethical Foundations & 24 & 12,6 \\
\hline Impact & 21 & 11,1 \\
\hline Legal Aspects & 19 & 10,0 \\
\hline Other & 17 & 8,9 \\
\hline Fiduciary Responsibility & 14 & 7,4 \\
\hline Universal Ownership & 8 & 4,2 \\
\hline Total & $\mathbf{1 9 0}$ & $\mathbf{1 0 0 , 0}$ \\
\hline
\end{tabular}

The majority of these studies (56.23) indicate that SRI fund performance is neutral compared to conventional (non-SRI) funds and broad stock market indices. This observation, which suggests that, in general, SRI strategies do not negatively impact on the risk-adjusted performance of funds, is of critical importance to institutional investors as it removes a key barrier to the pursuit of SRI. This finding is further strengthened by the fact that close to a quarter $(23.44 \%)$ of financial performance studies found that SRI funds outperformed conventional (non-SRI) funds and broad stock market indices. These findings on financial performance are likely to stimulate the demand for SRI funds (assuming, of course, that investors are rational and aware of the full universe of SRI funds available). Companies, in turn, are likely to feel increased pressure for improved ESG management and reporting. 


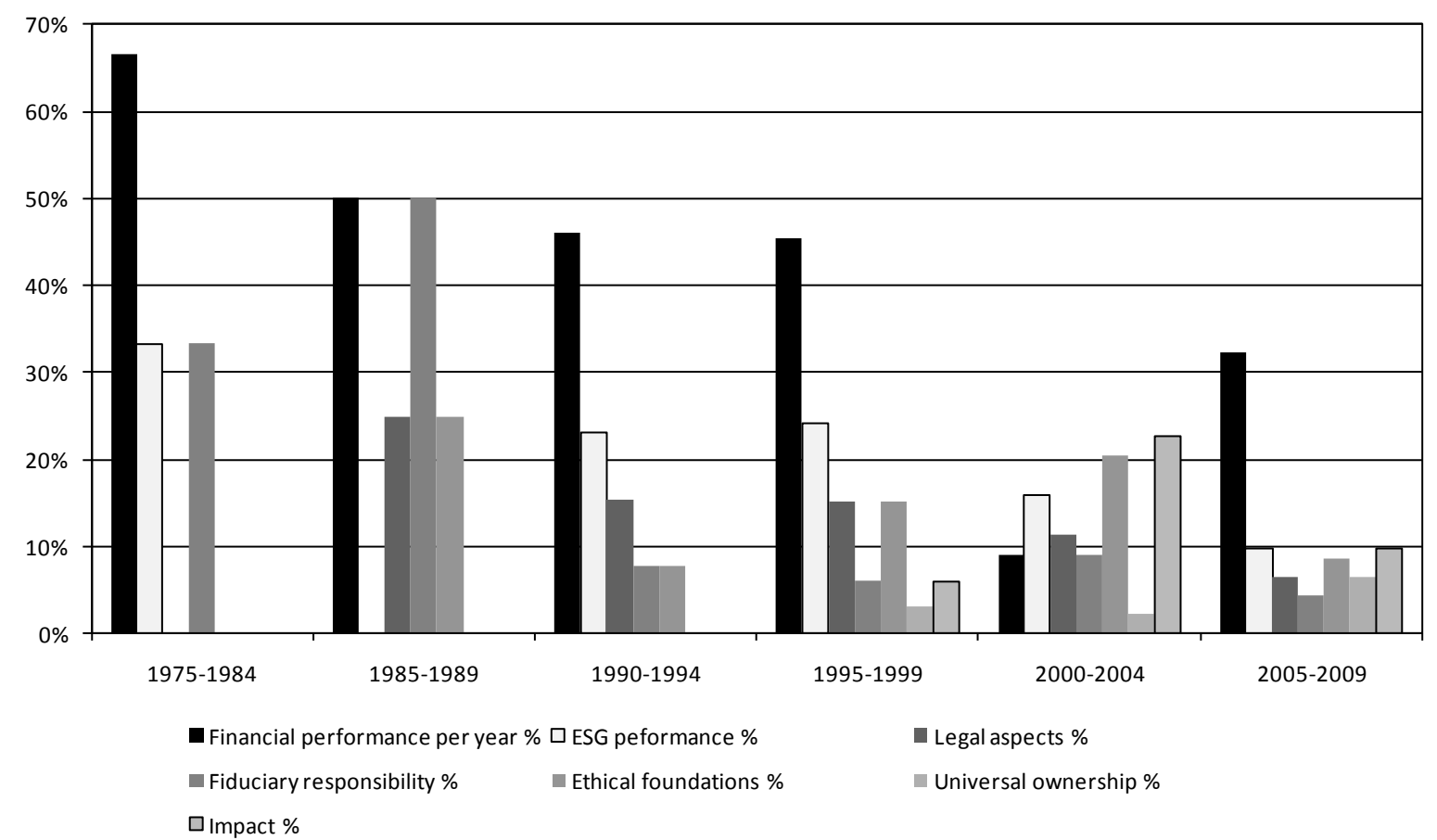

Figure 4: The appearance and frequency of themes in the sampled academic SRI literature

Only a fifth of studies $(20.31 \%)$ suggested that investing in a socially responsible manner represents a financial sacrifice. As indicated Figure 5, most of these studies were conducted in the earlier periods. These findings can, in many cases, be attributed to the use of small samples and inappropriate performance benchmarks (Gregory et al., 1997). Another shortcoming of some of the earlier SRI studies relates to the relatively short research periods investigated, some being as short as three years. Ideally, SRI fund performance should be evaluated over five to ten year periods to capture the full effect of market cycles (Akinjolire \& Smit, 2003: 45).

With the exception of a few recent studies (most notably Bauer et al., 2005), most prior studies on SRI fund performance suffer from a survivorship bias. This is a serious shortcoming as the exclusion of discontinued funds has been shown to lead to a significant overestimation of average fund performance (Brown, Goetzmann, Ibbotson \& Ross, 1992; Malkiel, 1995; Carhart, 1997). Liang (2000) explained that 'surviving funds' are most likely to be funds that have exhibited stronger performance or have indicated superior characteristics in order to stay in business.

In contrast, those funds that ceased operations are likely to have been poor performers that failed to satisfy the needs and niches of the mutual fund market. It should also be noted that the majority of financial performance studies defined SRI merely in terms of using a screening strategy. Different results could thus have been found had they used a broader definition of SRI i.e. one that included SRI funds employing shareholder activism and/or cause-based (targeted) investing strategies.

\section{ESG performance as a theme in SRI research}

The second most frequently addressed theme in the sample was that of ESG performance measurement. This theme has been addressed from various viewpoints. Several authors set out to establish a framework for evaluating how companies measure and monitor ESG risks (e.g. Sharfman, 1996; Dillenburg, Greene \& Erekson, 2003; Wisebrod, 2007), whereas others focused on ESG reporting (or rather the lack thereof). With regard to the latter, a large number of papers highlighted the need for improved ESG information to promote the SRI agenda (Harte, Lewis \& Owen, 1991; Friedman \& Miles, 2001; Hummels \& Timmer, 2004; Solomon \& Darby, 2005; Sonnenberg \& Hamman, 2006).

The lack of definitional clarity between the concepts of SRI, CSR (corporate social responsibility), CSI (corporate social investment) and ESG management, is very clear when considering the scope of articles dealing with these topics. Examples include CSR (Mackey, Mackey \& Barney, 2007); corporate social performance (Graves \& Waddock, 1994); social issues management (Coffey \& Fryxell, 1991); corporate social responsiveness (Vance, 1975); corporate citizenship (Waddock, 2000); corporate governance (Kiernan, 2007; Amao \& Amaeshi, 2008); and stakeholder salience theory (Neubaum \& Zahra, 2006).

From the papers evaluated it would appear that environmental, corporate governance and labour issues are becoming increasingly important for contemporary investors (Rivoli, 2003; Hudson, 2005; Ali, 2007; Vyvyan, Chew \& Brimble, 2007). A more detailed investigation is, however, necessary to determine the development and prominence of various ESG issues over time. 


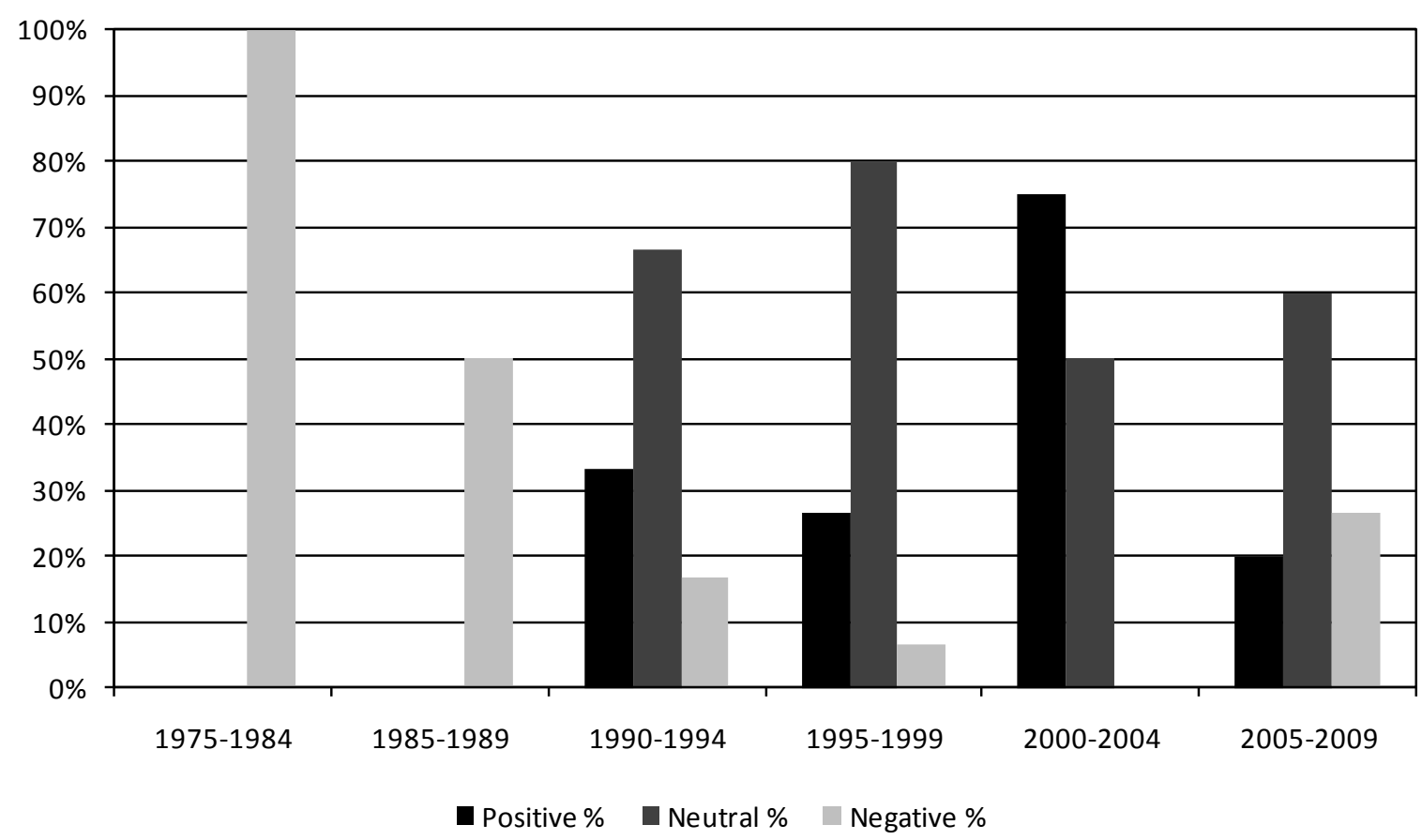

Figure 5: Financial performance over time (redrawn)

\section{Impact as a theme in SRI research}

Papers in this category essentially dealt with the impact of the various SRI strategies on the moral conscience of companies, and the effectiveness of SRI in promoting social change. Some of the earliest studies in this regard dealt with the effectiveness or ineffectiveness of shareholder activism in democratising South Africa (e.g. Teoh, Welch \& Wazzan, 1999).

Other studies investigated the impact of environmental screening on changing corporate environmental practices. An economic model developed by Barnea, Heinkel and Kraus (2005) showed that SRI investors in the USA have had a minimal impact on the cost of capital and share prices of polluting companies. Researchers such as Rivoli (2003) attributed this to the lack of market elasticity and small numbers of environmentally conscious investors compared to conventional investors in the US market. Yet other researchers focussed on the impact of community investing as a mechanism to uplift societies, stimulate social infrastructure development and encourage entrepreneurship (e.g. Heese, 2005; Hudson \& Wehrell, 2005; Lember, 2005; Lamore, Link \& Blackmond, 2006; Valor, Palomo, Iturrioz $\&$ Mateu, 2007).

\section{Legal aspects as a theme in SRI research}

As indicated earlier in Figure 4, research on the legal aspects of SRI was mainly conducted early on (1985-1989). Most of these studies, as well as later ones, make reference to shareholder activism as the most prominent SRI strategy, and also address the issue of fiduciary responsibility. Good examples in this regard include: Teoh et al. (1999), Solomon and Solomon (1999), McLaren (2004) as well as Rademeyer and Holtzhausen (2004). Tax law as a driver of SRI in the Netherlands was also highlighted by Scholtens (2005).
Finally, although excluded from this sample since it is a book, no review of literature pertaining to the legal aspects of SRI would be complete without at least noting Richardson's 2008 book on the subject.

\section{Fiduciary responsibility as a theme in SRI research}

Discussions of the fiduciary responsibility implications of SRI were a common feature in much of the early literature relating to the anti-apartheid SRI movement in the 1970s and 1980s. Beyond these, most articles dealing with fiduciary duty were written with reference to the pensionfund industry (e.g. Hylton, 1992; Cox et al., 2007) although Weber (2005) also made reference to fiduciary implications of SRI in the banking sector. Once again, Richardson's (2008) book is worthy of note in this regard, as is Hawley and Williams' (2000) book on fiduciary capitalism.

\section{Universal ownership as a theme in SRI research}

Universal ownership is the idea that many investors (particularly large institutional ones) do not own little bits of the economy, but rather own a piece of the whole economy (Hawley \& Williams, 2006). The theoretical implication is that externalising costs from one investment into the wider economy will in effect be paid for elsewhere in the portfolio. Together with long-termism, this has become a popular theoretical mechanism invoked to rationalise a general business case for considering ESG issues. However, despite the popularity of this mechanism, relatively little academic research has been done in this area. Academic publications reviewed in this study that specifically made reference to the idea of universal ownership were primarily (four out of eight) from a single special issue of the journal Corporate Governance (Volume 15, 2007). 


\section{Other themes frequently addressed by $S R I$ researchers over the past 35 years}

Two other themes: defining the concept of SRI, and commenting on the evolution and progression of SRI in specific countries and internationally, frequently featured in the literature reviewed. Articles that considered these themes often discussed the barriers, drivers and enablers of SRI and highlighted regional idiosyncrasies (e.g. Randjelovic et al., 2003; Schrader, 2006). Concerns about fiduciary responsibilities and financial performance were seen as by far the two most important barriers to the wider acceptance of SRI globally. Frequently mentioned drivers of SRI included the rise of shareholder activism (Solomon, Solomon \& Norton, 2002) as well as increased stakeholder advocacy by consumers and consumer groups (Krumsiek, 1997), NGOs (Guay, Doh \& Sinclair, 2004) and trade unions (Visser, 2005). Several studies centred on the construction, effectiveness and financial performance of SRI indices, such as the Domini 400 Social Index and the Dow Jones Islamic Market Indices (e.g. Vermeir, van de Velde \& Corten, 2005; Statman, 2006). Given evidence of the growing appetite for SRI noted in the introduction, several articles have focused on the profile of socially responsible investors (individuals) as well as their preferences and expectations, investment-decision-making styles, motives and levels of moral intensity (e.g. Farmen \& Van Der Wijst, 2005; Williams, 2007).

\section{Ethical foundations}

As indicated in Table 3, the ethical foundations of SRI as a specific research theme have featured prominently in this sample of literature. However, beyond these papers which specifically discuss ethics, a large proportion of the papers in the sample present some ethical position or positions at least implicitly. In an attempt to describe this, papers reviewed were characterised as 'presenting' one or more of the following ethical positions: utilitarianism, deontology, ethical egoism. An ambiguous category was also defined for cases where no ethical positions could reasonably be inferred. In order to achieve this characterisation, the basic definition set of ethical possibilities as articulated in Viviers, Bosch, Smit and Buijs (2008) was used. Accordingly, utilitarianism was taken to be the teleological approach in which the 'rightness' of a decision or action was judged based on the desired consequences of that decision or action. Papers that described SRI activity in which the ethical focus was on the societal end rather than the means, were thus coded as presenting examples of utilitarianism.

In contrast to utilitarianism, deontology is concerned with the moral obligations, duties or responsibilities which are inherently necessary for morality to prevail, irrespective of the ends or consequences they produce. Thus papers describing SRI activity in which decisions or actions were deemed ethical if they conformed to established moral principles were coded as presenting examples of deontology. The final ethical position considered was one of egoism where self-interest was the motivation for, and goal of, one's actions. Like utilitarianism, egoism is also a consequentialist ethical position, but in egoism the focus is on a positive outcome for the individual rather than for broader society.

The most commonly observed ethical positions in this sample were utilitarianism and deontology, with nearly $70 \%$ of the sample (132 papers) describing SRI activities which might reasonably be deemed to represent one or both of these ethical positions. Of the two, utilitarianism was the more frequently occurring (in about $63 \%$ of the sample). A deontological position was evident in around $40 \%$ of the sample. Many references (65 out of 132 papers) described SRI activities representing both positions. SRI activities deemed to be representative of ethical egoism were described in around $14 \%$ of the sample, while a fairly large proportion of the sample (nearly $28 \%$ ) was deemed to be ambiguous in terms of an ethical position.

Considering the appearance of these ethical positions over time (Figure 6), following an early spike in ambiguity, utilitarianism and deontology, have generally predominated over the entire sample period. Arguably the most interesting trend, however, is the apparent rise in references to the ethical egoist position. The earliest reference to such an ethical position in this sample was in a paper by Irvine in 1987, which considered the ethics of investing in general. From 1995 onwards, however, a continuous increase in the proportion of papers presenting an ethical egoist position is observable, and this was mirrored (although not exactly) by an apparent decline in the utilitarianism and deontology cluster. One might be tempted to suggest that this trend could be an empirical indication of a paradigm shift in SRI practice, which Richardson (2009: 555) describes as a 'renaissance of SRI in the mainstream financial markets since the late 1990s' towards 'business case SRI'.

This apparent rise in references to ethical egoist SRI and shift towards egoist SRI in mainstream financial markets noted by Richardson (2009) is worthy of comment. Egoism as an SRI approach has been justified from a moral perspective on the basis of the assumption or belief that investments with 'good' ESG records may exhibit enhanced financial performance, particularly over the long term and for universal owners (Griffin \& Mahon, 1997; Hillman \& Keim, 2001; Orlitzky, Schmidt \& Rynes, 2003). Accordingly, the argument goes that ethical egoist socially responsible investors no longer invest in a socially responsible manner because they believe it appropriate from a societal perspective, but rather because they believe it will benefit them financially. The major distinction that occurs between this ethical perspective and other ethical positions emerges when the interests of self are not aligned with broader societal interests or moral norms. Under these circumstances, the egoist investor will make investment decisions that will not be aligned with broader societal interests or moral norms (Eccles, 2010). 


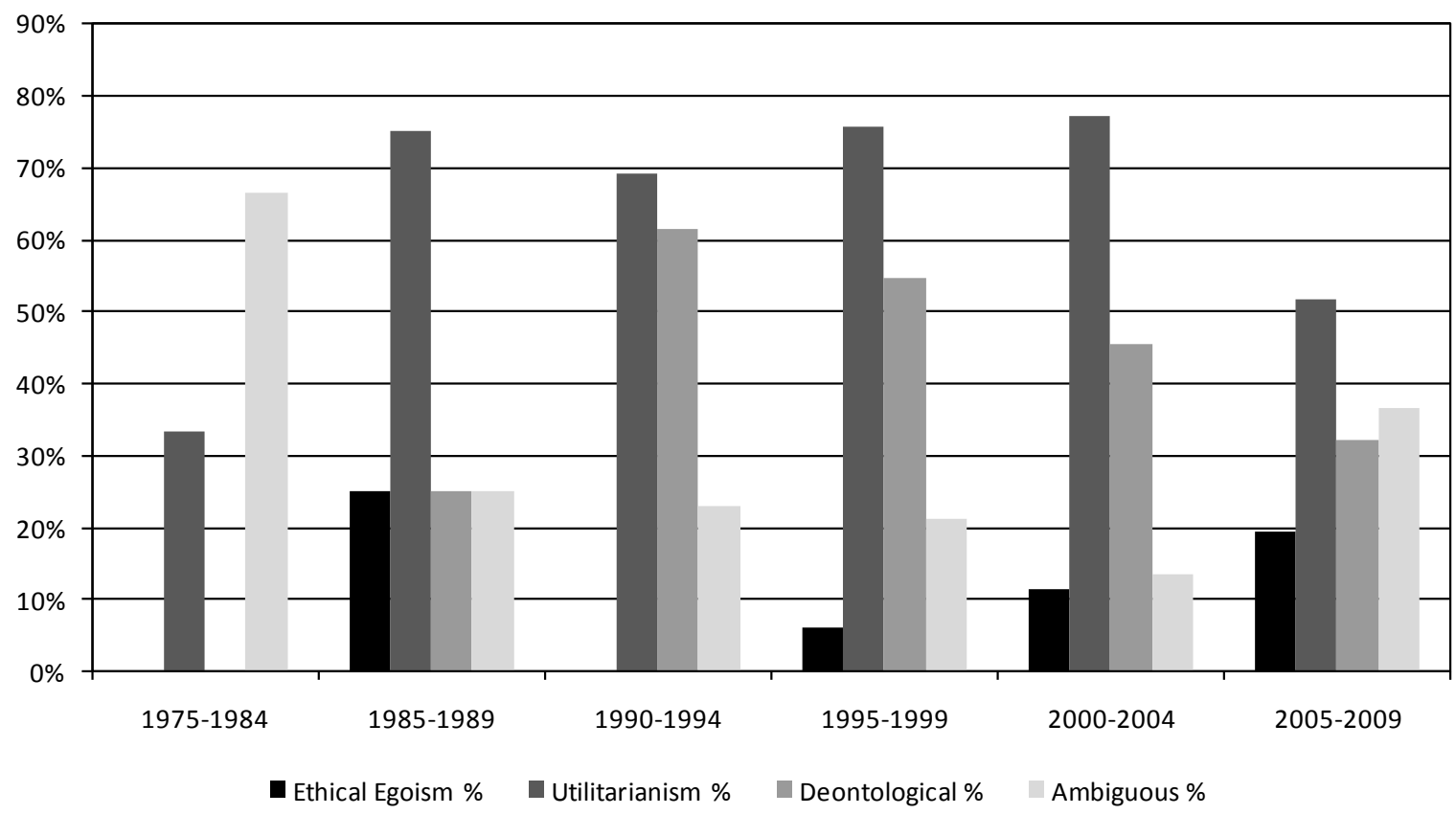

Figure 6: Ethical positions represented over time

The implications of this become particularly evident when considered with reference to the basic morality options of 'moral', 'amoral' and 'immoral'. In general, SRI has usually been assumed to be a form of moral investing, where the investor considers the moral implications of his/her investment activities and specifically chooses the moral option. Non-SRI, on the other hand, has generally been considered neither moral nor immoral, but rather as amoral. In other words, the investor does not consider the moral implications of his/her investment activities. Neither traditional SRI nor non-SRI is generally viewed to be immoral at a broader societal level. However, egoism as an ethical foundation may result in investment that is either moral or immoral at a broader societal level, depending on whether the interests of the investor are aligned with societal interests or not. This is a worrying realisation, and is certainly worthy of further research and debate.

\section{Research approach}

Without necessarily venturing into a detailed dissection of meta-science or research philosophy, considering the general research methodologies applied over 35 years of SRI research is an interesting lens through which to consider what burning questions academics in the field have grappled with. This is based on the assumption of a 'close means-end relationship between the methodological and epistemological dimensions' in social research (Mouton, 1996: 35). At the risk of trivialising the pursuit of knowledge, it is possible to broadly distil (post hoc) the questions that were detected in the sample into the following:

- What is SRI?

- How to do SRI?
- When, where and by whom has SRI been done?

- Why do SRI?

The first three of these questions are largely descriptive and lend themselves to a more (although not exclusively) qualitative methodological paradigm. Research approaches that would fall within this methodological paradigm would include descriptive literature reviews, case studies and interviews. In contrast, the fourth question is far less descriptive in nature and more about supporting or refuting a hypothesised business or social case for SRI, or modelling the relationship between investment performance and SRI practice. Given this, and the context within which SRI exists (namely the world of investment and the 'rational man'), this question lends itself to a quantitative methodological paradigm. Research approaches that would fall into this paradigm would include analyses of statistical (or market) data, surveys and experimental approaches.

Given the time-span involved in this sample, and the diverse sources from which it was drawn, it is hardly surprising that the sample contains representatives from both qualitative and quantitative methodological paradigms in almost equal measure (Figure 7).

The two most commonly observed methodologies were the more qualitative theoretical studies and literature reviews, and the more quantitative analyses of historical data. This suggests an almost equal split in the research objective of describing SRI activities and demonstrating or refuting the business (or social to a lesser extent) case for SRI. Considering when different research approaches dominated over time (Figure 8) adds a further nuance to previous findings. 


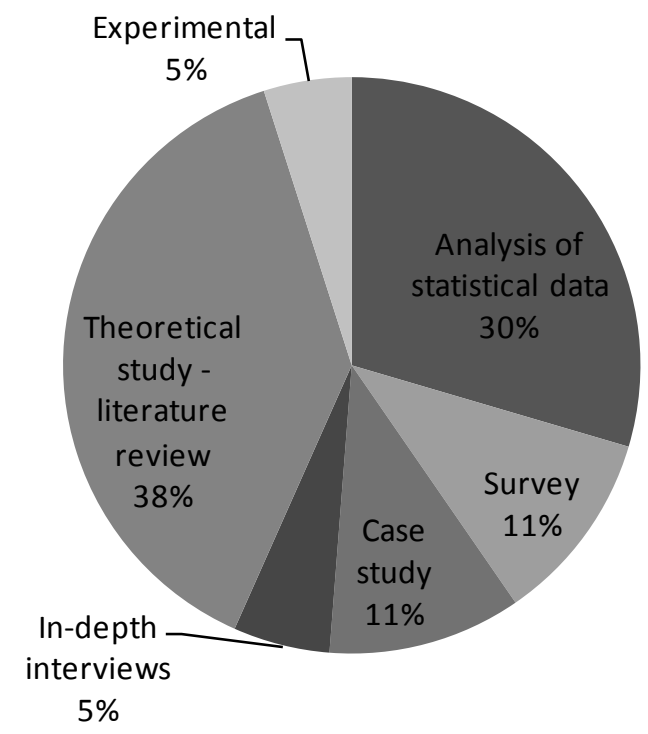

Figure 7: Overall frequency of the occurrence of various research approaches

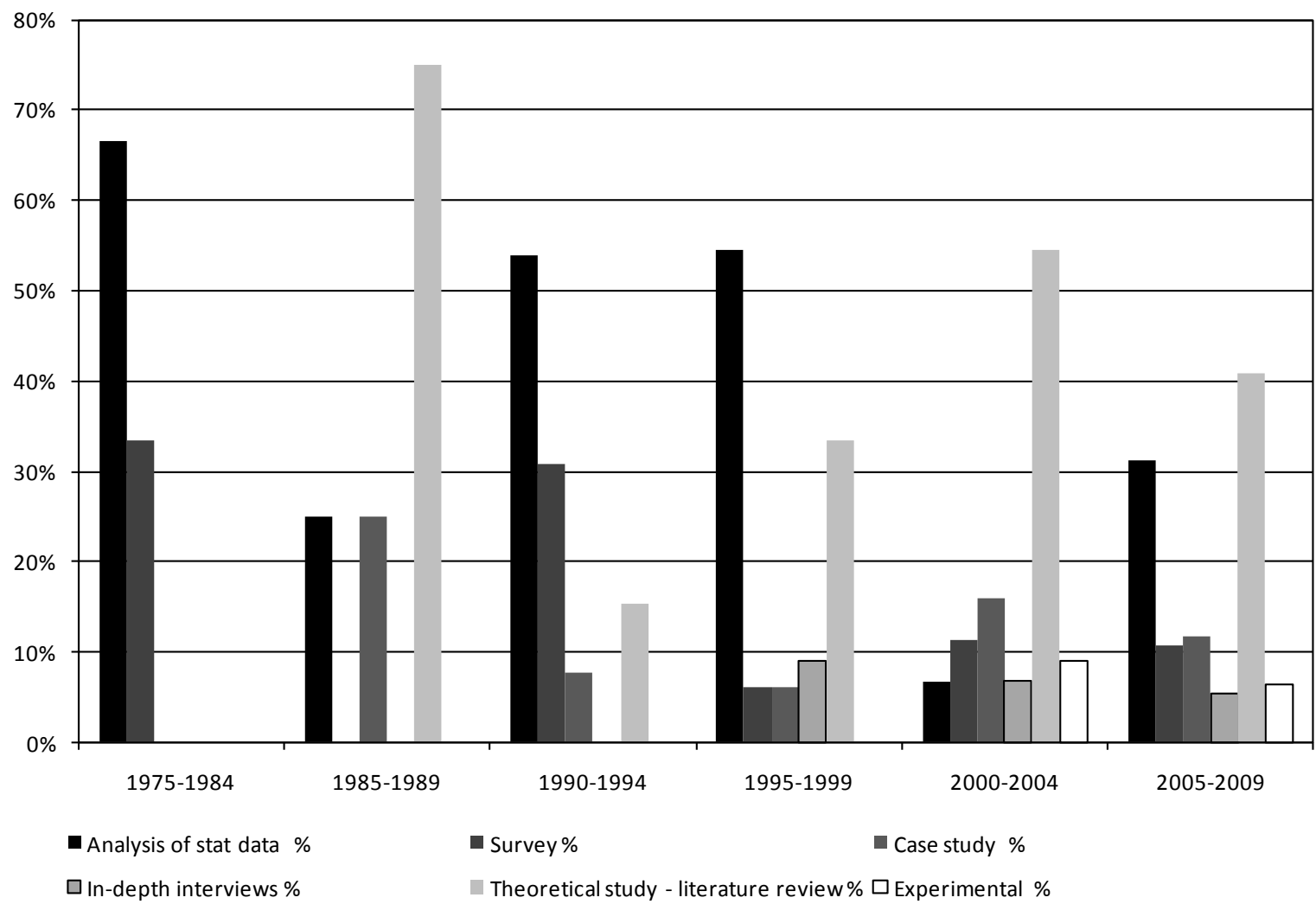

Figure 8: The appearance and frequency of research methodologies in the sampled academic SRI literature. Black bars indicate research approaches that tend to be qualitative while the grey bars indicate approaches that tend to be more quantitative in nature

The earliest papers sampled were exclusively quantitative, and in particular were dominated by studies attempting to examine the relationship between SRI and investment risk (e.g. Vance, 1975). Thereafter, an oscillation between a predominance of qualitative approaches and a predominance of quantitative approaches becomes apparent. This is most obvious when comparing the two most common research approaches in each category: namely the more qualitative theoretical studies and literature reviews, and the more quantitative analyses of historical data (Figure 8). On the one hand, this might suggest cycles of test, describe, adjust, hypothesise and test inherent in the scientific method. However, since these approaches are essentially mutually exclusive, and since they numerically dominate the sample, an oscillation is statistically inevitable. 
A more interesting observation, perhaps, is the apparent obsession with the business case for SRI that characterised the 1990s (from Luther, Matatko and Corner, 1992 through to Goldreyer and Diltz, 1999). As with the emergence of the egoist ethical position from 1995 onwards discussed in the previous section, it is interesting to consider this focus on the business case during the 1990s with reference to the 'renaissance of SRI in the mainstream financial markets since the late 1990s' referred to by Richardson (2009). One seemingly reasonable storyline to explain this focus on the business case during the $1990 \mathrm{~s}$ is that it might represent a very positivist attempt on the part of the academic community to demonstrate a business case with a view to encouraging the shift of SRI from the periphery of investment practice to the mainstream.

The swing away from this quantitative emphasis on the business case, back to the descriptive questions during the 2000s (e.g. Sparkes, 2001; Sparkes \& Cowton, 2004) could then indicate that the academic community had reached some sort of tacit consensus regarding the business case. This could have been that the business case had been adequately demonstrated, or that research saturation had been achieved and that further effort was deemed unlikely to yield fresh insights. Certainly the 'renaissance' in practice during the late 1990s noted by Richardson (2009) might indicate that the industry had been to a significant extent convinced of the business case of SRI. The focus on descriptive questions during the 2000 s could then point to some sort of collective need to reflect on the consequences of all of the efforts of the 1990s. Certainly Richardson's (2009) recent evaluation presents a stark criticism of how SRI has evolved. This sentiment echoes some of the pessimism expressed by Mackenzie in 2006.

\section{SRI strategies}

Three SRI strategies have dominated academic discussions over the past 35 years (Figure 9). These are negative screening, positive screening and shareholder activism, and very often all three are discussed in a single paper.

Although there have been some fluctuations in the apparent 'popularity' (or representation) of these strategies in the literature over the 35 years, none of the three have dipped below $25 \%$ of the sample in any of the periods (Figure 9). Cause-based (targeted) investing and best-in-sector, both derivatives of positive screening, have been a small but noteworthy feature of the literature since the 1990s. Enhanced analytics, which has become something of a buzz word in the SRI industry, has not been given any specific academic attention worth noting.

Where shareholder activism is concerned, some authors have drawn a distinction between shareholder activism and stakeholder advocacy. For example, Sparkes and Cowton (2004: 52) suggest that stakeholder advocacy is characterised by a single-issue focus, no financial interest, and the seeking of confrontation and publicity. They argue that this is in contrast with shareholder activism, which is characterised by multi-issue concerns, strong financial interests, the seeking of engagement with management, and the avoidance of publicity. However, this distinction has not received any wide acceptance. As such, it is reasonably safe to conclude that over 35 years of SRI research, three main SRI strategies have emerged, and remain the way SRI is 'done', at least as far as academia is concerned. Cause-based (targeted) investing as an SRI strategy is often discussed in relation to community development, community investment, impact investment, microfinance and 'channelling capital into socially useful projects' (Lamore et al., 2006).

\section{Conclusions and suggestions for future research}

From the figures presented and the narrative of several trends observed, the following future research imperatives stand out:

Primary Name: More than half of the papers reviewed (52\%) referred to investment practices that in some way integrate a consideration of ESG issues as SRI. Close to a quarter of researchers $(23 \%)$ also made reference to 'ethical investing'. Other names such as 'green investing' and 'responsible investing' are also becoming popular in the academic literature. Clarifying the precise meaning of various names, particularly the recently emerging names such as 'responsible investment', is worthy of further academic consideration.

Research Themes: The most frequently researched theme in the field of SRI over the past 35 years was that of financial performance, which was often discussed in relation to fiduciary responsibility and the legal aspects surrounding SRI. Despite this extensive body of literature on the financial performance of SRI, to date there has been no attempt to consolidate this in a robust formal review. Doing this is a pressing research imperative. Themes relating to the measurement and management of ESG issues as well as universal ownership and impact have been receiving increased attention from SRI researchers in recent years. An area that receives some inconclusive coverage is the area of the societal impact of SRI, and this is another area that would benefit from significant research investment.

Ethical Foundations: Although the ethical foundations were not always directly observable, the most frequently observable ethical position was that of utilitarianism. The apparent increase in references to an egoist ethical position in the latter periods in the sample is worthy of note, particularly in light of the temporal 'correlation' between this and a shift towards business case SRI noted by Richardson (2009) in industry. While possible consequences of this rise of egoism are briefly considered in the narrative, further research on this is required. 


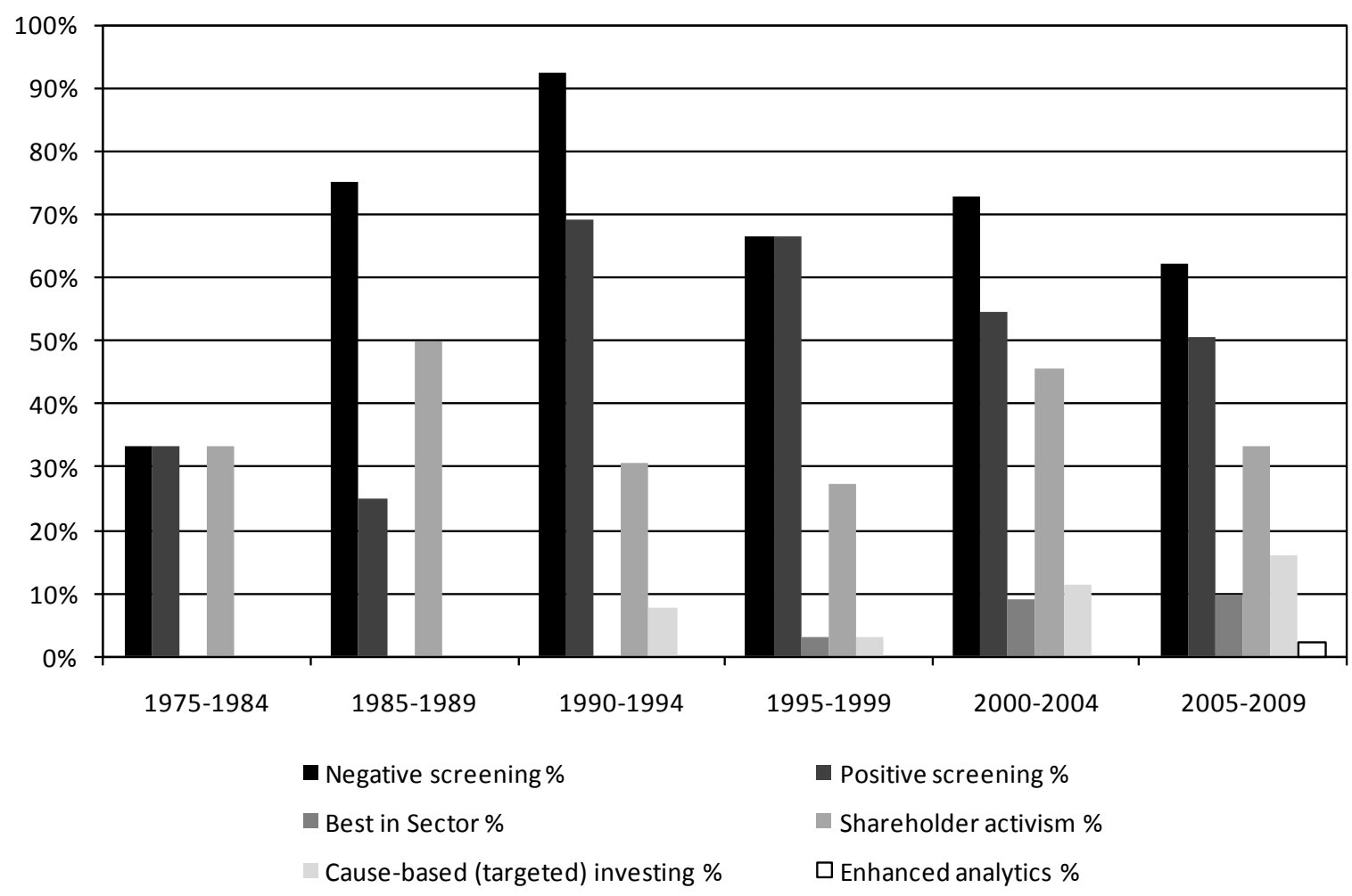

Figure 9: Overall frequency of the occurrence discussions of various SRI strategies in the sample

Research Approach: The most commonly observed research methodologies were the more qualitative theoretical studies and literature reviews, and the more quantitative analyses of historical data. This suggests an almost equal split relating to the research objective of describing SRI activities, and demonstrating or refuting the business (or to a lesser extent social) case for SRI. Interesting trends over time include the surge of studies focusing on resolving the business case in the 1990s, followed by a noticeable shift towards more qualitative approaches from 2000 onwards.

SRI Strategies: Three SRI strategies have dominated academic discussions over the past 35 years, namely negative screening, positive screening and shareholder activism. The SRI strategies of best-in-sector screening, cause-based (targeted) investing and enhanced analytics are featuring more prominently in more recent articles (20002009).

Based on the findings of this study and gaps identified in the literature, it is suggested that further research be undertaken on the Primary Name used to describe the conscious decision by investors to integrate ESG issues into investment analysis and ownership practices. The research could set out to establish whether certain names such as ethical investment, SRI and RI are related to key traits (such as investment strategy or the ethical position advocated), or whether their use is more a function of the period or place of their use.

The critical debate on the ethical foundations of SRI introduced in this paper, particularly those dealing with ethical egoism, deserves more attention.
Another area of research in the field could focus on the conditions favouring RI as well measuring the social impact of SRI funds. Particular attention could be paid to the impact of cause-based (targeted) investments. Further research is also required in clarifying the notion and implications of universal ownership.

A definite gap has been identified in this research in terms of SRI research being conducted in emerging economies. This might be due to the fact that SRI markets in these regions are currently still small and underdeveloped, or that some SRI articles in these regions have been published in languages other than English. More publications such as the one by Solomon, Solomon, and Suto (2004) entitled: 'Can the UK Experience Provide Lessons for the Evolution of SRI in Japan?' and 'SRI best practices - Learning from the Europeans' by White (2005), are required to stimulate debate and research on SRI in less-developed markets. Other studies could investigate whether there are differences in the SRI markets of emerging and developed economies, and if so, what causes these differences. The researchers are of the opinion that cultural differences could play a role.

Further research is also required into mechanisms-tomainstream SRI benchmarks. Finally, the business case for SRI needs closer inspection and critical review. It is suggested that this type of research takes the form of a metaanalysis of business-case papers. 


\section{References $^{1}$}

Akinjolire, A. \& Smit, E.vdM. 2003. 'South Africa unit trust performance and strategy in a changing economic climate', Investment Analysts Journal, 58: 41-50.

Ali, P. 2007. 'Investing in the environment: Some thoughts on the new breed of green hedge funds', Derivatives Use, Trading \& Regulation, 12(4): 351-357.

Amao, O. \& Amaeshi, K. 2008. 'Galvanising shareholder activism: A prerequisite for effective corporate governance and accountability in Nigeria', Journal of Business Ethics, 82(1): 119-130.

Barnea, A., Heinkel, R. \& Kraus, A. 2005. 'Green investors and corporate investment', Structural Change and Economic Dynamics, 16(3): 332-346.

Bauer, R., Koedijk, K. \& Otten, R. 2005. 'International evidence on ethical mutual fund performance and investment style', Journal of Banking and Finance, 29(7): 1751-1767.

Brown, S.J., Goetzmann, W., Ibbotson, R.G. \& Ross, S.A. 1992. 'Survivorship bias in performance studies', The Review of Financial Studies, 5(4): 553-580.

Carhart, M.M. 1997. 'On persistence in mutual fund performance', The Journal of Finance, 52(1): 57-82.

Coffey, B.S. \& Fryxell, G.E. 1991. 'Institutional ownership of stock and dimensions of corporate social performance: an empirical examination', Journal of Business Ethics, 10(6): 437-444.

Cox, P., Brammer, S. \& Millington, A. 2007. 'Pension fund manager tournaments and attitudes towards corporate characteristics', Journal of Business Finance \& Accounting, 34(7): 1307-1326.

Cummings, L.S. 2000. 'The financial performance of ethical investment trusts: An Australian perspective', Journal of Business Ethics' 25(1): 79-92.

Deborde, L., Minczeles, A. \& Sicard, J-P. 2006. 'Principes de l'investissement responsible : Une démarche des grands investisseurs institutionnels sous l'égide des Nations Unies', Revue d'Économie Financière, 85: 1-12.

Deheuvels,T. 2006. 'ISR: Un concept en devenir', Revue d'Économie Financière, 85: 1-10.

Dejean, F. 2008. 'La formation du marche de l'investissement socialement responsable en France', Economies et Societes, 42(1): 203-220.

\footnotetext{
1 References included are those specifically cited in the text. A complete list of the 190 articles that were included in the formal review is available from the authors on request.
}

Delahousse, L. 2006. 'À quelles conditions l'épargne retraite peut-elle contribuer au Développement de l'investissement socialement responsable?', Revue d'Économie Financière, 85: 1-12.

Dembinski, P., Bonvin J-M., Dommen, E. \& Monnet, F. 2003. 'The ethical foundations of responsible investment', Journal of Business Ethics, 48(2): 203-213.

Dillenburg, S., Greene, T. \& Erekson, H. 2003. 'Approaching socially responsible investment with a comprehensive ratings scheme: Total social impact', Journal of Business Ethics, 43(3): 167-177.

Diltz, J.D. 1995a. 'Does social screening affect portfolio performance?', Journal of Investing, Spring: 64-69.

Diltz, J.D. 1995b. 'The private cost of socially responsible investing', Applied Financial Economics, 5: 69-77.

Dunfee, T.W. 2003. 'Social investing: Mainstream or backwater?', Journal of Business Ethics, 43(3): 247-252.

Eccles, N.S. 2010. 'UN principles for responsible investment signatories and the anti-apartheid SRI movement: A thought experiment', Journal of Business Ethics, 95(3): 415-424.

Eurosif. 2008. 'European SRI Study 2008'. [online] URL:http://www.eurosif.org/publications/sri_studies.

Farmen, T.E.S. \& Van Der Wijst, N. 2005. 'A cautionary note on the pricing of ethics', Journal of Investing, 14(3): 53-56.

Feigenbaum, B. \& Lowenberg, A.D. 1988. 'South African disinvestment: Causes and effects', Contemporary Policy Issues, 6(4): 105-117.

Fernandez-Izquierdo, A. \& Matallin-Saez, J. 2008. 'Performance of ethical mutual funds in Spain: Sacrifice or premium?', Journal of Business Ethics, 81(2): 247-260.

Friedman, A.L. \& Miles, S. 2001. 'Socially responsible investment and corporate social and environmental reporting in the UK: An exploratory study', British Accounting Review, 33: 523-548.

Goldreyer, E.F. \& Diltz, J.D. 1999. 'The performance of socially responsible mutual funds: Incorporating sociopolitical information in portfolio selection', Managerial Finance, 25(1): 23-36.

Gond, J-P. 2006. 'Construire la relation (positive) entre performance sociétale et financière sur le marché de l'isr: de la performation a l'autoréalisation?', Revue d'Économie Financière, 85: 1-17.

Graves, S.B. \& Waddock, S.A. 1994. 'Institutional investors and corporate social performance', Academy of Management Journal, 37(4): 1034-1046. 
Gregory, A., Matatko, J. \& Luther, R. 1997. 'Ethical unit trust financial performance: small company effects and fund size effects', Journal of Business Finance and Accounting, 24(5): 705-724.

Griffin, J.J. \& Mahon, J.F. 1997. 'The corporate social performance and corporate financial performance debate', Business and Society, 36(1): 5-32.

Grossman, B.R. \& Sharpe, W.F. 1986. 'Financial implications of South African divestment', Financial Analyst Journal, July/August: 15-29.

Guay, T., Doh, J.P. \& Sinclair, G. 2004. 'Non-governmental organizations, shareholder activism and socially responsible investments: Ethical, strategic and governance implications', Journal of Business Ethics, 52(1): 125-139.

Guerard, J.B. 1997a. 'Is there a cost to being socially responsible in investing?', Journal of Investing, 6(2): 11-19.

Guerard, J.B. 1997b. 'Additional evidence on the cost of being socially responsible in investing', Journal of Investing, 6(4): 31-35.

Guerard, J.B. 1997c. 'Is there a cost to being socially responsible in investing?', Journal of Forecasting, 16: 475490.

Hamilton, S., Jo, H. \& Statman, M. 1993. 'Doing well while doing good? The investment performance of socially responsible mutual funds', Financial Analyst Journal, 49(6): 62-66.

Harte, G., Lewis, L. \& Owen, D. 1991. 'Ethical investment and the corporate reporting function', Critical Perspectives on Accounting, 2: 227-253.

Hawley, J.P. \& Williams, A.T. 2000. The rise of fiduciary capitalism. Philadelphia: University of Pennsylvania Press.

Hawley, J.P. \& Williams, A.T. 2006. 'The universal owner's role in sustainable economic development'. In Sullivan, R. \& Mackenzie, C. (Eds.). Responsible investment. Sheffield: Greenleaf Publishing.

Heese, K. 2005. 'The development of socially responsible investment in South Africa: Experience and evolution of SRI in global markets', Development Southern Africa, 22(5): 729-739.

Heinkel, R., Kraus, A. \& Zechner, J. 2001. 'The effect of green investment on corporate behaviour', Journal of Financial and Quantitative Analysis, 36(4): 431-449.

Hillman, A.J. \& Keim, G.D. 2001. 'Shareholder value, stakeholder value and social issues: What's the bottom line', Strategic Management Journal, 22: 125-139.

Hudson, R. 2005. 'Ethical investing: ethical investors and managers', Business Ethics Quarterly 15(4), 641-657.
Hudson, R. \& Wehrell, R. 2005. Socially responsible investors and the microentrepreneur: A Canadian case', Journal of Business Ethics, 60(3): 281-292.

Hummels, H. \& Timmer, D. 2004. 'Investors in need of social, ethical and environmental information', Journal of Business Ethics, 52(1): 73-84.

Hutton, R.B., D'Antonio, L. \& Johnsen, T. 1998. 'Socially responsible investing: Growing issues and new opportunities', Business and Society, 37(3): 281-306.

Hylton, M.O. 1992. "'Socially responsible" investing: Doing good versus doing well in an efficient market', American University Law Review, 42: 1-52.

Irvine, W.B. 1987. 'The ethics of investing', Journal of Business Ethics, 6: 233-242.

Kiernan, M.J. 2007. 'Universal owners and ESG: Leaving money on the table?', Corporate Governance, 15(3): 478485 .

Koellner, T., Sangwon, S., Weber, O., Moser, C. \& Scholz, R.W. 2007. 'Environmental impacts of conventional and sustainable investment funds compared using input-output life-cycle assessment', Journal of Industrial Ecology, 11(3): 41-60.

Kreander, N., Gray, G., Power, D.M. \& Sinclair, C.D. 2005. 'Evaluating the performance of ethical and non-SRI funds: A matched pairs analysis', Journal of Business Finance and Accounting, 32(7): 1465-1493.

Krumsiek, B.J. 1997. 'The emergence of a new era in mutual fund investing: Socially responsible investing comes of age', Journal of Investing, 6(4): 25-31.

Kurtz, L. \& DiBartolomeo, D. 1996. 'Socially screened portfolios: An attribution analysis of relative performance', Journal of Investing, 5(3): 35-41.

Lamore, R.L., Link, T. \& Blackmond, T. 2006. 'Renewing people and places: Institutional investment policies that enhance social capital and improve the built environment of distressed communities', Journal of Urban Affairs, 28(5): 429-442.

Lansing, P. \& Kuruvilla, S. 1988. 'Business divestment in South Africa: In who's best interest?', Journal of Business Ethics, 7(8): 561-574.

Lember, U. 2005. 'Corporate social responsibility and socially responsible investments according to the perceptions of Estonian institutional investors', EBS Review, 20: $88-98$.

Liang, X. 2000. 'Survivorship bias in mutual fund performance: Evidence in Canadian mutual funds'. Unpublished Master's dissertation, Concordia University, Montreal, Canada. 
Louche, C. \& Lydenberg, S. 2006. 'Investissement socialement responsible: Différences entre Europe et ÉtatsUnis', Revue d'Économie Financière, 85: 1-25.

Luther, R.G., Matatko, J. \& Corner, D.C. 1992. 'The investment performance of UK 'ethical' unit trusts', Accounting, Auditing and Accountability Journal, 5(4): 5770 .

Mackenzie, C. 2006. 'The scope for investor action on corporate social and environmental impacts'. In Sullivan, R. \& Mackenzie, C. (Eds.). Responsible investment. Sheffield: Greenleaf Publishing.

Mackenzie, C. 1998. 'The choice of criteria in ethical investment', Business Ethics: A European Review, 7(2): 8186.

Mackey, A., Mackey, T.B. \& Barney, J.B. 2007. 'Corporate social responsibility and firm performance: Investor preferences and corporate strategies', Academy of Management Review, 32(3): 817-835.

Malkiel, B.G. 1995. 'Returns from investing in equity mutual funds 1971 to 1991', Journal of Finance, 2: 549572.

McLaren, D. 2004. 'Global stakeholders: Corporate accountability and investor engagement', Corporate Governance: An International Review, 12(2): 191-201.

Meznar, M.B., Nigh, D. \& Kwok, C.C.Y. 1998. 'Announcements of withdrawal from South Africa revisited: Making sense of contradictory event study findings', Academy of Management Journal, 41(6): 715-730.

Mill, G.A. 2006. 'The financial performance of a socially responsible investment over time and a possible link with corporate social responsibility', Journal of Business Ethics, 63(2): 131-148.

Mouton, J. 1996. Understanding social research. Pretoria: Van Schaik.

Neubaum, D.O. \& Zahra. S.A. 2006. 'Institutional ownership and corporate social performance: the moderating effects of investment horizon, activism and coordination', Journal of Management, 32(1): 108-131.

Orlitzky, M., Schmidt, F.L. \& Rynes, S.L. 2003. 'Corporate social and financial performance: A meta analysis', Organization Studies, 24(3): 403-441.

Rademeyer, C. \& Holtzhausen, J. 2004. 'King II, corporate governance and shareholder activism', South African Law Journal, 120(4): 767-775.

Randjelovic, J., O'Rourke, A.R. \& Orsato, R.J. 2003. 'The emergence of green venture capital', Business Strategy and the Environment, 12(4): 240-253.
Renaudin, A. 2006. 'l'investissement socialement responsible: Le point de vue d'une mutuelle spécialiste en assurance-vie', Revue d'Économie Financière, 85: 1-5.

Reyes, M.G. \& Grieb, T. 1998. 'The external performance of socially responsible mutual funds', American Business Review, 16(1): 1-7.

Richardson, B.J. 2008. Socially responsible investment law. Oxford: Oxford University Press.

Richardson, B.J. 2009. 'Keeping ethical investment ethical: Regulatory issues for investing for sustainability', Journal of Business Ethics, 87(4): 555-572.

Rivoli, P. 2003. 'Labour standards in the global economy: Issues for investors', Journal of Business Ethics, 43: 223232.

Rudd, A. 1979. 'Divestment of South African equities: How risky?', Journal of Portfolio Management, 5(3): 5-10.

Sauer, D.A. 1997. 'The impact of social responsibility screens on investment performance: Evidence from the Domini 400 social index and Domini equity mutual fund', Review of Financial Economics, 6(2): 137-150.

Scholtens, B. 2005. 'What drives socially responsible investment? The case of the Netherlands', Sustainable Development, 3(2): 129-137.

Schrader, U. 2006. 'Ignorant advice - Customer advisory service for ethical investment funds', Business Strategy and the Environment, 15: 200-214.

Schueth, S. 2003. 'Socially responsible investing in the United States', Journal of Business Ethics, 43(3): 89-194.

Schwartz, M.S. 2003. 'The "ethics" of ethical investing', Journal of Business Ethics, 43(3): 195-231.

Schwartz, M.S., Tamari, M. \& Schwab, D. 2007. 'Ethical investing from a Jewish perspective', Business and Society Review, 112(1): 137-161.

Sharfman, M. 1996. 'The construct validity of the Kinder, Lydenberg \& Domini social performance ratings data', Journal of Business Ethics, 15: 287-296.

Social Investment Forum. 2007. 'Report on socially responsible investing trends in the United States'. [online]. URL: http://www.socialinvest.org/resources/research/

Solomon, J.F. \& Darby, L. 2005. 'Is private social, ethical and environmental reporting mythicizing or demythologizing reality?', Accounting Forum, 27(1): 27-47.

Solomon, A. \& Solomon, J.F. 1999. 'Empirical evidence of long-termism and shareholder activism in UK unit trusts', Corporate Governance: An International Review, 7(3): 288300. 
Solomon, J., Solomon, A. \& Norton, S. 2002. 'Socially responsible investment in the UK: Drivers and current issues', Journal of General Management, 27(3): 1-13.

Solomon, A., Solomon, J. \& Suto, M. 2004. 'Can the UK experience provide lessons for the evolution of SRI in Japan?', Corporate Governance: An International Review, 12(4): 552-566.

Sonnenberg, D. \& Hamman, R. 2006. 'The JSE Socially Responsible Investment Index and the state of sustainability reporting in South Africa', Development Southern Africa, 23(2): 305-320.

Sparkes, R. 2001. 'Ethical investment: Whose ethics, which investment?', Business Ethics: A European Review, 10(3): 194-205.

Sparkes, R. \& Cowton, C.J. 2004. 'The maturing of socially responsible investment: A review of the developing link with corporate social responsibility', Journal of Business Ethics, 52(1): 45-57.

Statman, M. 2000. 'Socially responsible mutual funds', Financial Analyst Journal, 56(3): 30-39.

Statman, M. 2006. 'Socially responsible indexes: Composition, performance, and tracking error', Journal of Portfolio Management, 32(3): 100-109.

Teoh, S.W., Welch, I. \& Wazzan, C.P. 1999. 'The effect of socially activist investment policies on the financial markets: Evidence from the South African boycott', Journal of Business, 72(1): 35-98.

Thamotheram, R. \& Wildsmith, H. 2007. 'Increasing longterm market returns: Realising the potential of collective pension fund action', Corporate Governance: $A n$ International Review, 15(3): 438-454.

Valor, C., Palomo, R., Iturrioz, J. \& Mateu, J.L. 2007. 'Socially responsible investments among savings banks and credit unions: Empirical findings in the Spanish context', Annals of Public and Cooperative Economics, 78(2): 301326.

Vance, S.C. 1975. 'Are socially responsible corporations good investment risks?', Management Review, 64(8): 18-24.

Vermeir, W., Van de Velde, E. \& Corten, F. 2005. 'Sustainable and responsible performance', Journal of Investing, 14(3): 94-100.

Visser, W.A.M. 2005. Corporate citizenship in South Africa - a review of progress since democracy. Journal of Corporate Citizenship, Summer(18): 29-38.

Viviers, S., Bosch, J.K., Smit, E.v.d M. \& Buijs, A. 2009. 'Responsible investing in South Africa', Investment Analysts Journal, 69(May): 1-17.
Viviers, S., Bosch, J.K., Smit, E.v.d. M. \& Buijs, A. 2008. 'Is responsible investing ethical?', South African Journal of Business Management, 39(1): 15-25.

Vyvyan, V., Chew, N. \& Brimble, M. 2007. 'Socially responsible investing: The green attitudes and grey choices of Australian investors', Corporate Governance: An International Review, 15(2): 370-381.

Waddock, S. 2000. 'The multiple bottom lines of corporate citizenship: Social investing, reputation, and responsibility audits', Business and Society Review, 105(3): 323-245.

Weber, O. 2005. 'Sustainability benchmarking of European banks and financial service organizations', Corporate Social Responsibility and Environmental Management, 12(2): 7387.

White, M.A. 1995. 'The performance of environmental mutual funds in the United States and Germany: Is there hope for "green" investors', Research in Corporate Social Performance, 1: 323-344.

White, C.F. 2005. 'SRI best practices: Learning from the Europeans', Journal of Investing, 14(3): 88-93.

Williams, G. 2007. 'Some determinants of the socially responsible investment decision: A cross-country study', Journal of Behavioural Finance, 8(1): 43-57.

Wisebrod, J.M. 2007. 'Social impact ratings: How to make responsible investment appealing', Finance and the Common Good/Bien Commun, 27: 29-40. 